\title{
VARIABILITY IN NEEDLE TRAITS OF PINUS MUGO TURRA IN THE UKRAINIAN CARPATHIANS
}

\author{
KRYSTYNA BORATYŃSKA ${ }^{1}$, NATAlia ANATOLIVNA PASHKEVICH ${ }^{2}$ \\ 'Polish Academy of Sciences, Institute of Dendrology \\ 62-035 Kórnik, Poland \\ e-mail: borkrys@rose.man.poznan.pl \\ ${ }^{2}$ National Academy of Science of Ukraine, Institute of Botany \\ Tereshchenkivs'ka 2, Kiev, Ukraine \\ e-mail: didukh@botan.kiev.ua
}

(Received: February 12, 2001. Accepted: May 23, 2001)

\begin{abstract}
Two-year-old needles were collected from 131 trees in 4 localities in the Eastern Carpathians in Ukraine. The needles were analysed in respect to 15 morphological and anatomical traits. The most stable appear to be needle width and thickness, and the ratio of needle thickness to width, while the distance between vascular bundles, Marcet's coefficient and number of resin canals were the most variable. Some of the analysed populations differ significantly from each other in the thickness of epidermal cells, number of resin canals and numbers of stomata on adaxial and abaxial surfaces of the needle.
\end{abstract}

KEY WORDS: pine, Ukraine, morphology, anatomy, statistical analysis.

\section{INTRODUCTION}

Pinus mugo Turra occurs in the mountains of central and southern Europe. Its westernmost localities are known from the Alps. Massif Central, Jura and Vosges Mts., while the easternmost ones from the Eastern and Southern Carpathians. In the western part of the species range and west of it in the Alps, Massif Central, Jura, Vosges Mts. and in the Pyrenees, the closely related species $P$. uncinata Ramond occurs. It is sometimes treated as a subspecies of P. mugo sensu lato (Christensen 1987a). Typical $P$. mugo is a mountain species with the centre of its occurrence in the subalpine zone, where it forms thicket communities above the upper forest limit. The most elevated stand of the species is known from the Alps and the Abruzzi Mts., from altitudes of about $2700 \mathrm{~m}$ (Hegi 1935; Jalas, Suominen 1973; Fenaroli, Gambi 1976; Welten, Sutter 1982). In the Ukrainian Carpathians $P$. mugo forms dense tickets, locally with abundant Juniperus communis subsp. nana Syme and Alnus viridis DC. These tickets are known as the association Pinetum mughi carpaticum and occur at altitudes between 1300 and $2000 \mathrm{~m}$ (Chopik 1976; Sokolov et al. 1977).

The main aim of the present study was to describe the range of variability of 15 anatomical and morphological traits of needles of Pinus mugo. The material was collected at 4 localities: 3 in the Charnokhora Mts. and 1 in the
Gorgan Mts. (Fig. 1), so their comparison enables an analysis of the geographical variability of this species in Ukraine. This is the first study of morphological variability of $P$. mugo from the Ukrainian Carpathians concerning needle traits. So far only cones of this species, coming from one population from Charnokhora Mts., were compared with 3 populations from the Western Carpathians (Staszkiewicz, Tyszkiewicz 1976).

\section{MATERIAL AND METHODS}

The needles for the study were collected in October 1997 (samples 1 and 2) or in September 1998 (samples 3 and 4) in the 4 natural localities of Pinus mugo in the Ukrainian Eastern Carpathians. Samples 1-3 come from the Charnokhora Mts. and sample 4 from the Gorgan Mts. (Table 1). Ten two-year-old short-shoots were gathered from the sunny side of 131 specimens, from fructifying shoots only. Each short-shoot was composed of two needles, so one needle was used for anatomical examination and the other needle was used for morphological examination. Consequently, a total of 1310 values of each of the studied traits were analysed statistically. Each shrub of $P$. mugo was analysed separately, and later the 4 local samples were analysed. The measurement procedures and equipment used were similar to those described in papers 


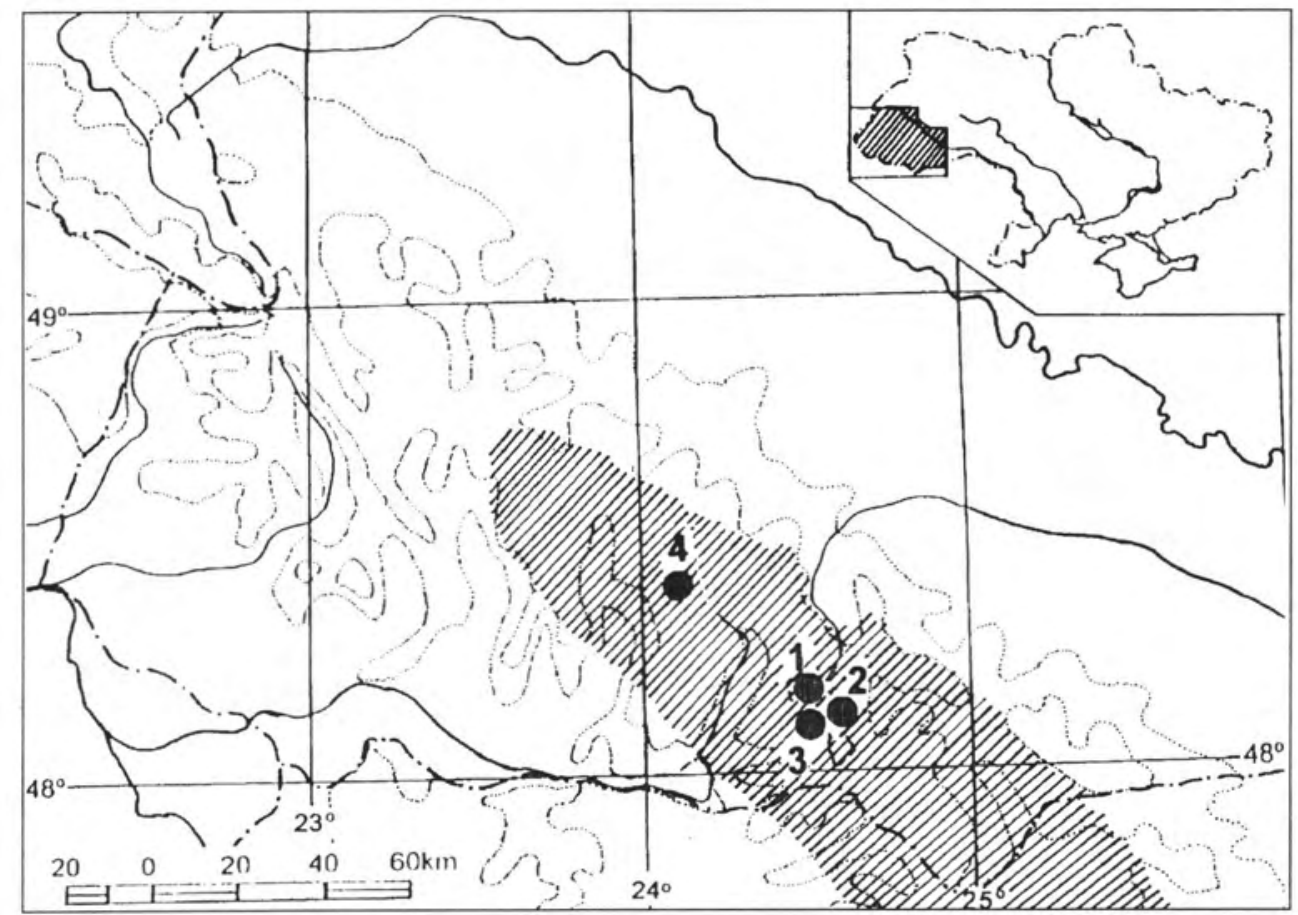

Fig. 1. Provenance of the studied material (1-4: sample numbers, description as in Table 1) against the background of Pinus mugo Turra range (hatched) in Ukraine (after Sokolov et al. 1977).
TABLE 1. Major characteristics of local samples of Pinus mugo needles.

\begin{tabular}{l|l|c|c}
\hline Samle no. & Locality & $\begin{array}{c}\text { Altitude } \\
(\mathrm{m} .)\end{array}$ & $\begin{array}{c}\text { No. of tested } \\
\text { specimens }\end{array}$ \\
\hline 1 & Charnokhora, Bresculec Mt. & $1600-1700$ & 36 \\
2 & Charnokhora, Khoverla Mt. & $1500-1600$ & 40 \\
3 & Charnokhora, Pogygevska Mt. & $1600-1750$ & 35 \\
4 & Gorgany Mts., Kanch Mt. & $1500-1550$ & 20 \\
\hline
\end{tabular}

by Boratyńska and Bobowicz (2000, 2001). The needle was described on the basis of 15 traits (Table 2). Additionally, we examined sclerenchyma cells around resin canals, and sclerenchyma cells between vascular bundles. The classifications of the cells followed Szweykowski (1969) and Bobowicz (1990).

The data obtained were analysed statistically using Statistica 5.1 software. Arithmetic means, standard deviations and variability coefficients were calculated for each

TABLE 2. Needle traits analysed.

\begin{tabular}{|c|c|c|}
\hline No. & Trait & Precision \\
\hline 1 & Needle length & $1 \mathrm{~mm}$ \\
\hline 2 & $\begin{array}{l}\text { Number of stomatal rows on convex (abaxial) side } \\
\text { of needle }\end{array}$ & \\
\hline 3 & Number of stomatal rows on flat (adaxial) side of needle & \\
\hline 4 & $\begin{array}{l}\text { Number of stomata on } 2 \mathrm{~mm} \text { long section of needle, } \\
\text { on convex (abaxial) side }\end{array}$ & \\
\hline 5 & $\begin{array}{l}\text { Number of stomata on } 2 \mathrm{~mm} \text { long section of needle, } \\
\text { on flat (adaxial) side }\end{array}$ & \\
\hline 6 & Number of resin canals & \\
\hline 7 & Needle width & $0.1 \mathrm{~mm}$ \\
\hline 8 & Needle thickness & $0.1 \mathrm{~mm}$ \\
\hline 9 & Distance between vascular bundles & $1 \mu \mathrm{m}$ \\
\hline 10 & Thickness of epidermial cells & $1 \mu \mathrm{m}$ \\
\hline 11 & Width of epidermal cells & $1 \mu \mathrm{m}$ \\
\hline 12 & Marcet's coefficient (=traits $9 \times 7 / 8)$ & $1 \mu \mathrm{m}$ \\
\hline 13 & Stomatal rows ratio (=traits $2 / 3$ ) & \\
\hline 14 & Needle thickness/width ratio (=traits $8 / 7$ ) & \\
\hline 15 & Width/thickness ratio of epidermal cells (=traits 11/10) & \\
\hline
\end{tabular}

trait. The analysis of variance was made to detect traits that significantly differentiated the specimens and local samples. The interactions between individual traits were examined using the Pearson's linear correlation coefficient. The analyses were made within the 4 local samples and then for all the material, treated as one sample. For the comparison of the local samples, dendrograms were constructed on the basis of Euclidean distances, by the nearest-neighbourhood cluster analysis (Marek 1989; Morrison 1990; Moczko et al. 1998, Statistica for Windows 5.1). Differences and similarities between the local samples were also shown using the graphic methods developed by Jentys-Szaferowa (1959).

\section{RESULTS}

Mean values, ranges and standard deviations of the investigated traits are presented for the local samples separately and for all the analysed specimens combined (Table 3 ). Means of most of the traits were similar in all 4 localities. Only few of them manifested greater differences. The specimens were much more differentiated than local samples. The largest differences were found in the distance between vascular bundles (trait 9), as mean values for individual specimens varied from 56.9 to $84.3 \mu \mathrm{m}$.

Variability coefficients of individual traits for the analysed population of $P$. mugo ranged from $6 \%$ to $38 \%$ (Fig. 2). Needle dimensions, particularly width and thickness (traits 7 and 8 ) and the ratio of needle thickness to width (trait 14) were always the most stable. Numbers of stomata on adaxial and abaxial surfaces (traits 4 and 5) were also stable. The most variable was the distance between vascular bundles (trait 9). Its minimum value (6.6 $\mu \mathrm{m})$ was recorded for specimens from Khoverla and Pogygevska, while the maximum (almost $210 \mu \mathrm{m}$ ) for one needle of a specimen from Khoverla. Marcet's coefficient was also highly variable, but this only reflected the variability in the distance between vascular bundles. The num- 
TABLE 3. Major statistical characteristics of the analysed 15 needle traits of $P$. mugo (numbers 1-15, full names as in Table 2).

\begin{tabular}{|c|c|c|c|c|c|c|c|c|c|c|c|c|c|c|c|c|}
\hline \multirow{2}{*}{$\begin{array}{l}\text { Calculated } \\
\text { characteristics }\end{array}$} & \multirow{2}{*}{$\begin{array}{l}\text { Analysed } \\
\text { samples }\end{array}$} & \multicolumn{15}{|c|}{ Measure characters } \\
\hline & & 1 & 2 & 3 & 4 & 5 & 6 & 7 & 8 & 9 & 10 & 11 & 12 & 13 & 14 & 15 \\
\hline \multirow{9}{*}{$\begin{array}{l}\text { Arithmetic } \\
\text { mean }\end{array}$} & Bresculec Mt. & 5.01 & 8.66 & 6.45 & 19.00 & 19.45 & 3.39 & 1263.00 & 749.09 & 73.71 & 23.10 & 14.16 & 124.57 & 1.36 & 0.59 & 0.62 \\
\hline & Khoverla & 4.87 & 8.53 & 6.28 & 20.58 & 20.49 & 3.59 & 1312.20 & 769.40 & 84.28 & 23.54 & 14.48 & 144.39 & 1.38 & 0.58 & 0.62 \\
\hline & Pogygevska & 5.06 & 8.33 & 6.17 & 19.76 & 19.59 & 3.10 & 1270.27 & 755.34 & 73.25 & 21.08 & 14.03 & 123.77 & 1.37 & 0.59 & 0.67 \\
\hline & Gorgan Mts & 5.51 & 7.99 & 5.67 & 19.72 & 19.22 & 3.08 & 1223.27 & 753.47 & 56.91 & 21.87 & 14.55 & 92.91 & 1.43 & 0.61 & 0.67 \\
\hline & $\begin{array}{l}\text { All } \\
\text { analyse specimens }\end{array}$ & 5.08 & 8.43 & 6.20 & 20.01 & 19.77 & 3.33 & 1273.90 & 757.63 & 74.25 & 22.51 & 14.29 & 125.58 & 1.38 & 0.6 & 0.65 \\
\hline & Bresculec Mt. & 3.30 & 5.00 & 4.00 & 10.00 & 10.00 & 0.00 & 935.00 & 595.00 & 9.90 & 13.32 & 11.09 & 19.98 & 0.83 & 0.48 & 0.35 \\
\hline & Khoverla & 3.10 & 5.00 & 3.00 & 14.00 & 14.00 & 2.00 & 988.75 & 488.75 & 6.66 & 13.32 & 11.09 & 9.99 & 0.83 & 0.41 & 0.37 \\
\hline & Pogygevska & 3.30 & 5.01 & 4.00 & 15.00 & 10.00 & 0.00 & 977.50 & 595.00 & 6.66 & 11.66 & 11.09 & 11.35 & 0.71 & 0.47 & 0.47 \\
\hline & Gorgan Mts & 3.70 & 6.00 & 4.00 & 15.01 & 15.00 & 2.00 & 1020.00 & 616.25 & 13.32 & 16.65 & 11.09 & 21.54 & 0.85 & 0.51 & 0.41 \\
\hline \multirow[t]{5}{*}{ Minimum } & $\begin{array}{l}\text { All } \\
\text { analyse specimens }\end{array}$ & 3.10 & 5.00 & 3.00 & 10.00 & 10.00 & 0.00 & 935.00 & 488.75 & 6.66 & 11.66 & 11.09 & 10.00 & 0.71 & 0.42 & 0.36 \\
\hline & Bresculec Mt. & 7.00 & 14.00 & 9.00 & 29.00 & 29.00 & 6.00 & 1508.75 & 913.75 & 133.20 & 39.96 & 16.65 & 247.37 & 2.33 & 0.86 & 1.00 \\
\hline & Khoverla & 7.50 & 12.00 & 10.00 & 27.00 & 27.00 & 6.00 & 1700.00 & 1062.50 & 209.79 & 29.97 & 27.74 & 407.92 & 2.50 & 0.73 & 1.04 \\
\hline & Pogygevska & 6.80 & 12.00 & 9.00 & 24.00 & 25.00 & 6.00 & 1530.00 & 1041.25 & 149.85 & 29.97 & 23.31 & 265.98 & 2.25 & 0.79 & 1.00 \\
\hline & Gorgan Mts & 7.20 & 12.00 & 8.00 & 25.00 & 24.00 & 5.00 & 1434.38 & 871.25 & 116.55 & 33.30 & 16.65 & 198.13 & 2.50 & 0.70 & 1.00 \\
\hline \multirow[t]{5}{*}{ Maximum } & $\begin{array}{l}\text { All } \\
\text { analyse specimens }\end{array}$ & 7.50 & 14.00 & 10.00 & 29.00 & 29.00 & 6.00 & 1700.00 & 1062.50 & 209.79 & 39.96 & 27.74 & 407.93 & 2.50 & 0.86 & 1.00 \\
\hline & Bresculec Mt. & 0.73 & 1.43 & 0.98 & 2.02 & 2.06 & 0.80 & 89.30 & 56.56 & 23.50 & 3.16 & 1.89 & 40.40 & 0.26 & 0.04 & 0.10 \\
\hline & Khoverla & 0.74 & 1.41 & 1.08 & 2.09 & 2.24 & 0.73 & 118.20 & 67.11 & 31.67 & 3.37 & 1.92 & 56.67 & 0.24 & 0.03 & 0.11 \\
\hline & Pogygevska & 0.76 & 1.25 & 0.99 & 1.76 & 1.92 & 0.86 & 103.27 & 65.64 & 27.14 & 3.13 & 1.83 & 47.17 & 0.25 & 0.03 & 0.11 \\
\hline & Gorgan Mts & 0.91 & 1.35 & 0.97 & 1.73 & 1.76 & 0.75 & 92.39 & 51.68 & 22.46 & 3.15 & 1.86 & 38.43 & 0.28 & 0.03 & 0.11 \\
\hline $\begin{array}{l}\text { Standard } \\
\text { deviation }\end{array}$ & $\begin{array}{l}\text { All } \\
\text { analyse specimens }\end{array}$ & 0.79 & 1.38 & 1.04 & 1.97 & 2.09 & 0.82 & 107.07 & 62.23 & 28.42 & 3.37 & 1.89 & 50.17 & 0.26 & 0.04 & 0.11 \\
\hline
\end{tabular}

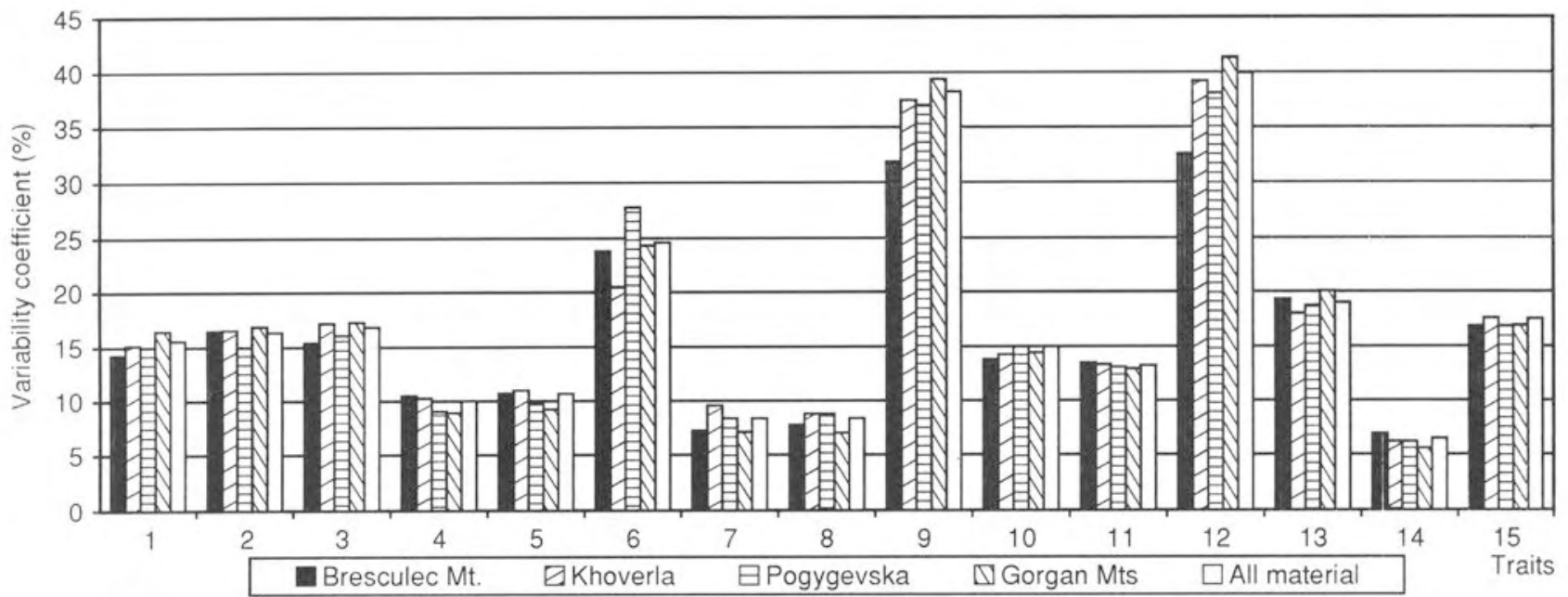

Fig. 2. Variability coefficients for 4 samples of Pinus mugo and for all analysed material combined (1-15: trait numbers as in Table 2).

ber of resin canals (trait 6) at needle cross-section was also highly variable. Some needles without resin canals were observed. while up to 6 canals were found in others. Variability coefficients of individual traits were very similar in all 4 local samples of $P$. mugo.

The analysis of variance (ANOVA) was used to check the significance of differences between specimens and between local samples. ANOVA of the results of measurements of 10 needles from each of the 131 specimens showed that all the traits analysed significantly differentiate specimens (Table 4). Analysis of differences between local samples showed statistically significant differences in only a few traits. The thickness of epidermal cells (trait 10), width/thickness ratio of epidermal cells (trait 15), number of resin canals (trait 6) and numbers of stomata on adaxial and abaxial surfaces of the needle (traits 4 and 5) showed statistically significant differences between some of the compared samples (Table 5).

Correlation was observed between many of the studied needle traits of $P$. mugo. The most significant $(\alpha=0.05)$ positive linear correlation was found between needle width and thickness (traits 7 and 8), with Pearson's coefficient value of +0.71 . Positive correlations with lower levels of significance were recorded between the numbers of stomata on adaxial and abaxial surfaces of the needle (traits 4 and 5), and between needle width and the distance between vascular bundles (traits 7 and 9). Negative correlations between the needle traits were small and generally insignif- 
TABLE 4. Results of analysis of variance for 131 specimens of Pinus mugo (based on measurement of 1310 needles, each specimen represented by 10 needles).

\begin{tabular}{crc}
\hline $\begin{array}{c}\text { Character } \\
\text { no. }\end{array}$ & $\begin{array}{c}\mathrm{F} \\
\text { statistic }\end{array}$ & $\begin{array}{c}\mathrm{p} \\
\text { value }\end{array}$ \\
\hline 1 & 53.809 & 0.000 \\
2 & 9.191 & 0.000 \\
3 & 7.467 & 0.000 \\
4 & 9.855 & 0.000 \\
5 & 9.637 & 0.000 \\
6 & 10.885 & 0.000 \\
7 & 23.622 & 0.000 \\
8 & 20.937 & 0.000 \\
9 & 15.464 & 0.000 \\
10 & 7.405 & 0.000 \\
11 & 2.307 & 0.000 \\
12 & 15.437 & 0.000 \\
13 & 2.398 & 0.000 \\
14 & 6.197 & 0.000 \\
15 & 4.399 & 0.000 \\
\hline
\end{tabular}

icant. Coefficients of correlation between the traits within individual local samples are comparable with those calculated for all specimens combined. Higher correlation coefficients were observed only in the sample from Khoverla, between the numbers of stomatal rows on abaxial and adaxial surfaces of the needle (traits 2 and 3 ) and between needle width and thickness (traits 7 and 8 ).

The presence of sclerenchyma cells around resin canals is typical for P. mugo. They have thick walls and a large, distinct lumen. Such sclerenchyma cells prevail in the sample from Pogygevska. The cells with intermediately thick walls and not so large but still distinct lumen were observed in sclerenchyma of the other 3 local samples. Nevertheless, fibres with thick walls and a small lumen occurred sporadically in needles from all 4 local samples.

Sclerenchyma cells between vascular bundles were also of the kind typical for $P$. mugo, characterised by thick cell walls and a large, conspicuous lumen. These cells were dominant in the needles collected in the populations from Bresculec, Pogygevska and the Gorgan Mts. The intermediate type of cells with somewhat thicker cell walls and a smaller lumen was observed only in the needles from Khoverla. The fibre-like cells were very rare and occurred only singly in needles from all local populations.

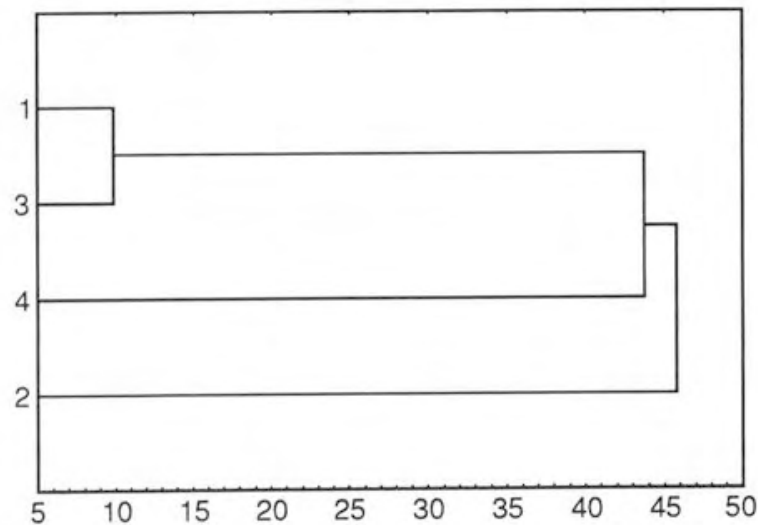

Fig. 3. Dendrogram based on Euclidean distances of 11 measurable morphological and anatomical needle traits (1-4: sample numbers as in Table 1).
TABELA 5. Results of analysis of variance between 4 local samples of Pinus mugo, based on measurement of 15 characters (average of 10 needles for each specimen).

\begin{tabular}{ccc}
\hline $\begin{array}{c}\text { Character } \\
\text { no. }\end{array}$ & $\begin{array}{c}F \\
\text { statistic }\end{array}$ & $\begin{array}{c}p \\
\text { value }\end{array}$ \\
\hline 1 & 1.036 & 0.379 \\
2 & 0.750 & 0.524 \\
3 & 1.083 & 0.358 \\
4 & 2.838 & 0.041 \\
5 & 3.968 & 0.010 \\
6 & 6.123 & 0.001 \\
7 & 2.299 & 0.081 \\
8 & 1.378 & 0.252 \\
9 & 2.055 & 0.109 \\
10 & 11.549 & 0.000 \\
11 & 2.108 & 0.102 \\
12 & 2.381 & 0.073 \\
13 & 0.154 & 0.927 \\
14 & 1.576 & 0.198 \\
15 & 8.789 & 0.000 \\
\hline
\end{tabular}

Using cluster analysis, we obtained dendrograms based on traits 1-11 (Fig. 3). Only two groups of populations could be distinguished in the dendrograms. One group, composed of local populations from Bresculec and Pogygevska, shows very close relations. Populations from Gorgan Mts. and Khoverla are rather distinct from them and also from each other.

The comparison of the mean values of individual traits of local samples, made parallel to the Jentys-Szaferowa method of comparing plant shapes, demonstrated that all 4 local samples are very similar (Fig. 4). The samples from Pogygevska and Bresculec were particularly similar, and close to the general mean values calculated on the basis of all material combined. The samples from Khoverla and the Gorgan Mts. differ from the previous ones in the distance between vascular bundles (trait 9), in Marcet's coefficient (traits 12), and - to a lesser degree - in the numbers of stomatal rows on both surfaces of the needle (traits 2 and 3 ), the number of resin canals (trait 6), and needle length (trait 1).

\section{DISCUSSION}

The morphological and anatomical variability of $P$. mugo needles has been the subject of several studies. These investigations contributed to a better characterization of the species and provided some new data concerning the taxonomic position of the species (Jährig 1964, Marcet 1967; Montacchini, Caramiello 1968; Szweykowski 1969; Staszkiewicz, Tyszkiewicz 1972; Szweykowski et al. 1976; Szweykowski, Bobowicz 1977; Musil 1977; Viewegh 1981; Bobowicz et al. 1983; Christensen 1987b; Bobowicz 1988, 1990; Christensen, Dar 1997; Minghetti 1997).

The results of the present study enabled a detailed description of morphological and anatomical traits of $P$. mugo needles from Ukraine. The comparison of the obtained mean values of the analysed traits with those known from previous studies place the Ukrainian populations of $P$. mugo close to Christensen's „P. mugo east" from the mountains of Slovenia (Christensen 1987b). This similarity concerns especially needle dimensions and the 


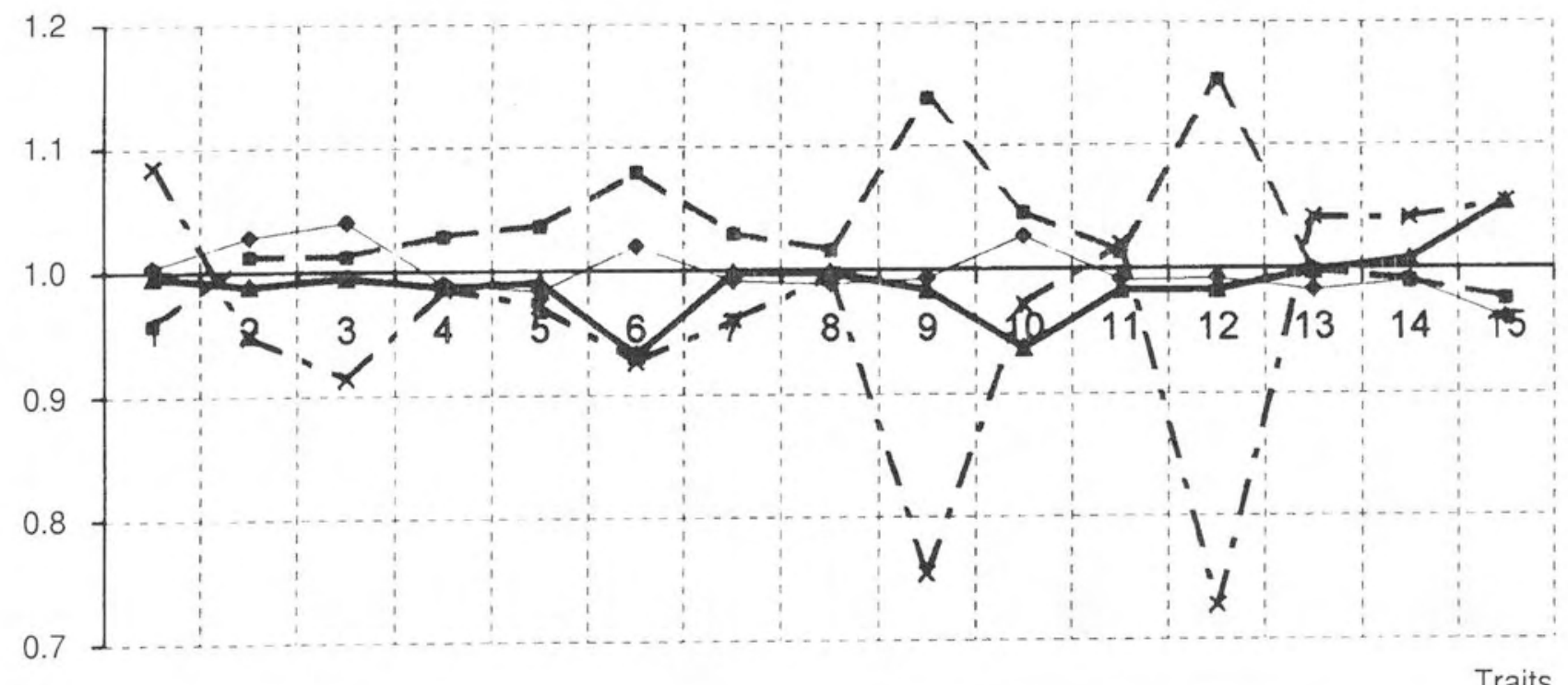

Traits

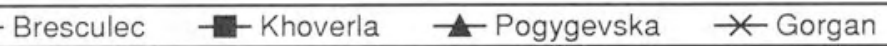

Fig. 4. Comparison of 4 local samples of Pinus mugo by Jentys-Szaferowa's (1959) graphic methods.

distance between vascular bundles. The needles from Ukraine, however, were slightly larger than those from Christensen's (1987b) study. The mean number of resin canals at needle cross-section in our material was 3.3, compared to 4.7 reported by Christensen (1987b). Epidermal cells (traits 10,11 and 15) are rectangular in our material, similarly as in Christensen's (1987b), but somewhat less elongated.

The mean thickness of epidermal cells in P. mugo needles from Ukraine was significantly smaller than in needles from the Tatra Mts., as it amounted to 21.1-23.5 $\mu \mathrm{m}$ and 26.9-29.5 um (Bobowicz, Krzakowa 1986, 1988), respectively. The mean width of epidermal cells was very similar in both mountain ranges, as it amounted to $14.2-16.1 \mu \mathrm{m}$ in the Tatra Mts. and 14.0-14.6 $\mu \mathrm{m}$ in Ukraine. Similarly, both populations did not manifest significant differences in the number of resin canals (in the Tatra Mts. 3.6-4.6). The distance between vascular bundles (trait 9) in needles from Ukraine was somewhat shorter than in needles from Tatra Mts. (57-84 $\mu \mathrm{m}$ in Ukraine, $70-110 \mu \mathrm{m}$ in the Tatra Mts.).

The most variable traits in the populations from Ukraine and Tatra Mts. included the distance between vascular bundles (trait 9), Marcet's coefficient (trait 12) and number of resin canals (trait 6). The variability coefficients of these three traits for the Ukrainian samples were greater than for samples from the Tatra Mts. (Bobowicz, Krzakowa 1986).

\section{ACKNOWLEDGEMENTS}

The authors wish to thank Dr J. Petrovich Didukh from the Institute of Botany in Kiev (Ukraine) and Dr A. Boratyński from the Institute of Dendrology in Kórnik (Poland) for collection of the plant material and for critical revision of the manuscript.

This study was partly sponsored by the Polish Committee for Scientific Research, grant No 6PO4G 06016.

\section{LITERATURE CITED}

BOBOWICZ M.A. 1988. Differentiation of Pinus sylvestris L., Pinus mugo Turra, pines from „Bór na Czerwonem” and from Zieleniec in traits of one and two-year-old cones. Bull. Soc. Amis Sci. Lett. Poznań, ser. D, 26: 99-108.

BOBOWICZ M.A. 1990. Mieszańce Pinus mugo Turra $\times$ Pinus sylvestris L. z rezerwatu „Bór na Czerwonem” w Kotlinie’ Nowotarskiej. Uniwersytet im. Adama Mickiewicza w Poznaniu, ser. Biologia, 40: 5-270. Poznań.

BOBOWICZ M.A., KRZAKOWA M. 1986. Anatomical differences between Pinus mugo Turra populations from the Tatra Mts. expressed in needle traits and in needle and cone traits together. Acta Soc. Bot. Pol. 55, 2: 275-290.

BOBOWICZ M.A., KRZAKOWA M. 1988. Variability of Pinus mugo Turra individuals from Hala Gąsienicowa in Tatra Mts expressed in needle traits with reference to cone characters. Bull. Soc. Amis Sci. Lett. Poznań, ser. D, 26: 87-98.

BOBOWICZ M.A., SZWEYKOWSKI J., KOŹLICKA M. 1983. The variability of morphological traits in the population of Pinus mugo Turra on Borowina Peat Bog in the Izerskie Mts. (SW Poland). Bull. Soc. Amis Sci. Lett. Poznań, ser. D, 22: 83-105.

BORATYŃSKA K., BOBOWICZ M.A. 2000. Variability of Pinus uncinata Ramond ex DC. as expressed in needle traits. Dendrobiology, 45: 7-16.

BORATYŃSKA K., BOBOWICZ M.A. 2001. Pinus uncinata Ramond taxonomy based on needle characters. Plant Syst. Evol. (in print).

CHOPIK 1976. Visokogirna flora Ukrainskich Karpat. Kijev, pp. 22-23.

CHRISTENSEN K.I. 1987a. Taxonomic revision of the Pinus mugo complex and $P . \times$ rhaetica $(P$. mugo $\times$ sylvestris) (Pinaceae). Nordic Journal of Botany 7 (4): 383-408.

CHRISTENSEN K.I. 1987b. A morphometric study of the Pinus mugo Turra complex and its natural hybridization with $P$. sylvestris L. (Pinaceae). Feddes Repert. 98, 11-12: 623-635.

CHRISTENSEN K.I.B, DAR G.H. 1997. A morphometric analysis of spontaneous and artificial hybrids of Pinus mugo $\times$ sylvestris (Pinaceae). Nord. J. Bot. 17 (1): 77-86. 
FENAROLI L., GAMBI G. 1976. Alberi. Museo Tridentino di Science Naturali, Triento.

HEGI G. 1935. Illustrierte Flora von Mitteleuropa, 1: 125-132. München.

JALAS J., SUOMINEN J. 1973. Atlas Florae Europaeae, 2. Committee for Mapping the Flora of Europe and Societas Biologica Fennica Vanamo, Helsinki, 21.

JÄHRIG M. 1964. Beiträge zur Nadelanatomie und Taxonomie der Gattung Pinus L. Willdenowia, 3: 329-366.

JENTYS-SZAFEROWA J. 1959. Graficzna metoda porównywania kształtów roślinnych. Nauka Polska, 7: 79-110.

MARCET E. 1967. Über den Nachweis spontaner Hybriden von Pinus mugo Turra und Pinus silvestris L. aufgrund von Nadelmerkmalen. Berichte der Schweizerischen Botanischen Gesellschaft, 77: 314-361.

MAREK T. 1989. Analiza skupień w badaniach empirycznych. PWN, Warszawa, pp. 1-47.

MINGHETTI P. 1997. Contributo alla conoscenza di Pinus mugo agg. in Trentino (Italia): un approccio biometrico. Webbia 52 (1): 67-85.

MOCZKO A.J., BRĘBOROWICZ G.H., TADEUSIEWICZ R. 1998. Statystyka w badaniach medycznych. Springer PWN, Warszawa, pp. 1-122

MONTACCHINI F., CARAMIEllo R. 1968. Il Pinus mugo Turra ed il Pinus uncinata Miller in Piemonte. Note critiche e disribuzione. Giorn. Bot. Ital. 102: 529-535.

MORRISON D.F. 1990. Wielowymiarowa analiza statystyczna. PWN, Warszawa, 7-589.

MUSIL I. 1977. Variabilita znaků jehlic u komplexu Pinus mugo a u Pinus sylvestris. Preslia 49: 23-32.
SOKOLOV S., JA, SVJAZEVA O.A., KUBLY V.A. 1977. Arealy derevev i kustarnikov SSSR, 1. Nauka, Leningrad, 33-34.

STASZKIEWICZ J., TYSZKIEWICZ M. 1972. Zmienność naturalnych mieszańców Pinus sylvestris L. $\times$ Pinus mugo Turra $(=P . \times$ rotundata Link $)$ w południowo-zachodniej Polsce oraz na wybranych stanowiskach Czech i Moraw. Fragm. Flor. et Geobot. Ann. 18, 2: 173-191.

STASZKIEWICZ J., TYSZKIEWICZ M. 1976. Zmienność populacyjna i osobnicza szyszek kosodrzewiny (Pinus mugo Turra) ze szczególnym uwzględnieniem materiałów z Karpat. Fragm. Flor. et Geobot. 22: 1-2: 19-28.

Statystyka dla Windows I: Ogólne konwencje i Statystyki I. 1997. Praca zbiorowa zespołu StatSoft Polska.

SZWEYKOWSKI J. 1969. The variability of Pinus mugo Turra in Poland. Bulletin de la Société des Amis des Lettres de Poznań, Ser. D. 10: 39-54.

SZWEYKOWSKI J., BOBOWICZ M.A. 1977. Variability of Pinus mugo Turra in Poland IV. Needles and cones in some Polish populations. Bull. Soc. Amis Sci. Lett. Poznań, ser. D, 17: 3-14.

SZWEYKOWSKI J., MENDELAK M., BOBOWICZ M.A. 1976. The variability of $P$. mugo Turra in Poland. II. An artificial seashore population. Bull. Soc. Amis. Sci. Lett. Poznań, ser. D, 16: 3-16.

VIEWEGH J. 1981. Variabilita hybridniho roje Pinus mugo $\times$ Pinus sylvestris na rašeliništi u Zuberce na Oravě. Folia dendrologica 8: 41-58.

WELTEN M., SUTTER H.C.K. 1982. Verbreitungatlas der FarnBlütenpflanzen der Schweiz, vol. 1. Birkhäuser Verlag, Basel, Boston, 86-87.

\section{ZMIENNOŚĆ IGIEŁ PINUS MUGO TURRA Z KARPAT UKRAIŃSKICH}

\section{STRESZCZENIE}

Praca zawiera szczegółową analizę zmienności igieł $P$. mugo. Materiał pochodził z 4 naturalnych stanowisk ze 131 drzew z ukraińskich Karpat. W badaniach uwzglẹdniono 15 cech morfologicznych i anatomicznych a uzyskane wyniki poddano analizie statystycznej. Ustalono, że najbardziej stabilnymi cechami okazały siẹ szerokość (cecha 7), grubość igły (cecha 8) i stosunek między tymi cechami (cecha 14). Współczynnik zmienności dla tych cech wahał siẹ miẹdzy $5,4 \%$ a $9,6 \%$. Natomiast do cech najbardziej zmiennych należy odległość miẹdzy wiązkami przewodzącymi, współczynnik Marceta oraz liczba kanałów żywicznych. Współczynnik zmienności dla ostanich cech siẹgał niekiedy nawet $40 \%$. Analizowane próby pochodzące z różnych miejsc zbioru statystycznie istotnie różniły siẹ między sobą wysokością komórek epidermy (cecha 10), ilorazem wymiarów komórek epidermy (cecha 15), liczbą kanałów żywicznych (cecha 6) i liczbą szparek po obydwu stronach igły (cechy 4 i 5 ).

SŁOWA KLUCZOWE: kosodrzewina, Ukraina, morfologia, anatomia, statystyki. 